\title{
Tax morals and the Brazilian citizen: an empirical study
}

\author{
ANTONIO LOPO MARTINEZ ${ }^{1}$ \\ MARCELO LOPES Bello COELHO ${ }^{2}$ \\ 1 Universidade de CoImbra / PÁtIO da Universidade, CoIMBra, PorTugaL \\ 2 Universidade Vale do Rio doce (UniVAle) / CAmpus Armando VieIra, Governador Valadares - MG, BraziL
}

\begin{abstract}
This study analyzes the tax morals of the Brazilian citizen, aiming to measure its level, as well as if there is a difference of the tax morals in the sociodemographic characteristics. Tax morale is an important determinant of compliance with tax legislation, so measuring it and evaluate each aspect that determines it allows to strategize and ensure better fiscal conformity. The research period was between May and August 2017, with 679 participants. The questionnaire adapted from the work of Torgler, Schaffner, and Maclntyre (2007), with multiple choice objective questions allowed the collection of data from individuals and was applied indirectly, electronically, validated by the use of the Cronbach's alpha. The results showed in medium terms a neutral or partially contrary perception of the practice of tax evasion. As far as gender is concerned, the results indicate that women generally have higher tax morals than men. Regarding religion it has been demonstrated that spiritualists have higher tax morals compared to participants from other religions. As for education, the higher the formal education, the higher the tax moral. The results are relevant and meaningful, and help to better understand the challenge of tax compliance, as well as offer elements to insire future research on the subject, considering its theoretical and social relevance, and the fact that it is little studied in Brazil.
\end{abstract}

Keywords: Tax morals. Fiscal compliance. Tax evasion.

\section{Moral tributária e o cidadão brasileiro: estudo empírico}

\section{Resumo}

Este estudo analisa a moral tributária do cidadão brasileiro, almejando quantificá-la, bem como identificar se existe diferença na moral tributária no que tange às características sociodemográficas. A moral tributária é um importante determinante do cumprimento da legislação fiscal, portanto, aferi-la e avaliar cada aspecto que a determina possibilita traçar estratégias e assegurar melhor conformidade fiscal. O período compreendido foi de maio a agosto de 2017 e a pesquisa teve 679 participantes. O questionário, adaptado de Torgler, Schaffner e Macintyre (2007), com perguntas objetivas de múltipla escolha, possibilitou a coleta de dados de pessoas físicas e foi aplicado indiretamente, de maneira eletrônica, e validado com base no coeficiente alfa de Crombach. Os resultados evidenciaram, em termos médios, uma percepção neutra ou parcialmente contrária à prática da evasão fiscal. No que diz respeito ao gênero, os resultados indicam que, em geral, as mulheres têm maior moral tributária do que os homens; já em relação à religião, restou demonstrado que os espíritas têm maior moral tributária em comparação com os participantes que declararam outras religiões; no que concerne à educação, percebeu-se que quanto maior a instrução formal, maior a moral tributária. Conclui-se que os resultados obtidos são pertinentes e significativos e, certamente, ajudam a compreender o desafio do compliance tributário, assim como podem subsidiar novas investigações acerca do tema, dada sua relevância teórica e social e o pioneirismo desta iniciativa de pesquisa no Brasil.

Palavras-chave: Moral tributária. Conformidade fiscal. Evasão fiscal.

\section{La moral tributaria y el ciudadano brasileño: estudio empírico}

\section{Resumen}

Este estudio analiza la moral tributaria del ciudadano brasileño, con el objetivo de cuantificarla, así como para identificar si hay una diferencia en la moral tributaria en lo que respecta a las características sociodemográficas. La moral tributaria es un determinante importante del cumplimiento de la legislación fiscal, por lo tanto, cotejarla y evaluar cada aspecto que la determina, permite elaborar estrategias y garantizar una mejor conformidad fiscal. El período de la encuesta fue entre los meses de mayo y agosto del año 2017, con 679 participantes. El cuestionario adaptado de Torgler, Schaffner y Maclntyre (2007), con preguntas objetivas de elección múltiple, permitió la recolección de datos de personas físicas, se aplicó indirecta y electrónicamente, y se validó por el uso del coeficiente alfa de Crombach. Los resultados mostraron, en términos medios, una percepción neutra o parcialmente contraria a la práctica de la evasión fiscal. En lo que se refiere al género, los resultados indican que las mujeres generalmente tienen una mayor moral tributaria que los hombres. Por otro lado, con relación a la religión, se ha demostrado que los espiritistas tienen una mayor moral tributaria en comparación con los participantes que han declarado otras religiones; En lo que respecta a la educación, se ha observado que cuanto más alta es la educación formal, mayor es la moral tributaria. Se concluye que los resultados obtenidos son relevantes y significativos, y sin duda ayudan a comprender mejor el reto del cumplimiento tributario, así como pueden contribuir a nuevas investigaciones sobre el tema, dada la relevancia teórica y social y el carácter inédito en Brasil.

Palabras clave: Moral tributaria. Cumplimiento fiscal. Evasión fiscal. 


\section{INTRODUCTION}

This study proposes to analyze the tax morale of Brazilian citizens. Its essential objective is to offer an instrument to quantify and trace a preliminary diagnosis of this morale in terms of its socio-demographic characteristics.

Gerstenblüth, Melgar, Pagano et al. (2012), Doerrenberg and Peichl (2013), Luttmer and Singhal (2014), Alm and McClellan (2012), Filippin, Fiorio and Viviano (2013) and Horodnic (2018) are some of the authors who, through their studies, point to tax morale as an important determinant in tax compliance, and the analysis of this construct can help improve the understanding of taxpayer behavior. From the positioning of various researchers in terms of the importance of tax morale, defined as the motivation to pay taxes, is a determinant factor in tax evasion and tax compliance (DOERRENBERG and PEICHL, 2013).

The term tax morale uses morale in the sense of morals. The Priberam Dictionary of the Portuguese Language (PRIBERAM INFORMÁTICA, 2017) defines moral (morale) as something that proceeds with justice, that which is correct, decent, honest, has integrity, is just and principled. It can further be described as a group of values in terms of human conduct and good manners. Luttmer and Singhal (2014) define tax morale as voluntary compliance with tax legislation, including non-pecuniary motivations. Gerstenblüth, Melgar, Pagano et al. (2012) explain this term as the intrinsic motivation of individuals to pay taxes. Doerrenberg and Peichl (2013) confirm this definition, indicating that this inherent motivation arises from a moral obligation to pay taxes to contribute to society. Filippin, Fiorio and Vivianno (2013) also present tax morale as a non-monetary factor which is not related to a system of compensation and sanctions. These preliminary studies conceive of tax morale as an internal obligation to pay taxes (BRAITHWAITE and AHMED, 2005) or a commitment to civic duty (ORVISKA and HUDSON, 2003).

Torgler (2005) highlights, in fact, the existence of a negative correlation between tax evasion and tax morale. The author argues that tax evasion is a way for taxpayers to demonstrate their dissatisfaction and antipathy toward the government, which may be due to the poor performance of public administration or the implementation of complex tax rules. The idea that the better management of public resources increases tax morale is the subject of a study by Barone and Mocetti (2011).

Within this context, Nichita and Batrâncea (2012) argue that there is a positive correlation between tax morale and tax compliance: tax compliance increases in proportion to an increase in tax morale. Pope and Mohdali (2010) emphasize, in fact, that a country's culture and the individual behavior of its citizens are social factors that counterbalance other economic models, which are necessary to study tax morale and, as a consequence, the causes of a lack of tax compliance.

The relevance of this study is the fact that it is necessary to understand that tax morale can be emphasized as something that influences tax compliance within a socio-economic context (NICHITA and BATRÂNCEA, 2012). Moreover, Doerrenberg and Peichl (2013) address the existence of strong evidence that tax morale affects the behavior of citizens in terms of paying taxes. Recognizing the determinants of tax morale can contribute to the fight against tax evasion. Thus, the discussion of tax morale has been gaining more and more prominence internationally, especially in terms of how it can help in the understanding of which factors interfere with the tax morale of Brazilians.

This study seeks to examine this realistically and disseminate this knowledge, given that a discussion of tax morale has been shown to be of importance in observing the taxation environment (SANTIAGO, 2015). In this sense, we seek to contribute to the flow of information addressing taxation in the literature. This is a pioneering study in Brazil because it consists of a pilot project which applies a survey developed and applied by Torgler, Schaffner and Macintyre (2007) to quantify the concept of tax morale. Even though the results are preliminary, there are indications that this methodology can be applied to Brazil, because the results are clear and demonstrate trends which will be analyzed from this perspective. 


\section{THEORETICAL REFERENCES}

Researchers have analyzed on a more detailed level sophisticated economic models that seek to explain the motives that lead taxpayers to avoid paying taxes, but they do not explain high levels of tax compliance (LUTTMER and SINGHAL, 2014; WILLIAMS and KRASNIQI, 2017).

One of them, the economic model of crime, proposed by Becker (1968), played a prominent role in the initial approach to tax morale. This study considers sanctions to be the main element of enforcement to combat tax evasion. However, based on this exposition, the mention of this variable raises the need to consider the existence of intrinsic factors in tax compliance, given that the standard approaches have been insufficient to explain tax evasion behavior (TORGLER, 2002).

Another model is the type of tax evasion analysis performed by Allingham and Sandmo (1972), in which the main point of analysis is dissuading tax evasion through the imposition of penalties.

When considering other cultural, behavioral and sociological factors, it is important to take into account the influence of tax morale when analyzing the level of tax compliance (MOLERO and PUJOL, 2012).

Torgler, Schaffner and Macintyre (2007) seek to diagnose the reasons behind tax compliance, reinforcing the perspective that it is necessary to investigate the dominant determinants of tax morale. This study considers it to be an important condition for tax compliance, given that the results indicate a strong negative correlation between tax morale and tax evasion. The authors identify that in countries in which there is systematic corruption and government spending is neither transparent nor responsible, citizens do not feel an obligation to pay taxes. This work demonstrates that the older the taxpayer, the more this person will avoid tax evasion. On the other hand, people who are divorced or separated have less tax morale, as do autonomous workers. A commitment to a church, however, is correlated with greater tax morale. It concludes, therefore, that tax morale is a relevant aspect in the determination of tax compliance and tax evasion.

Luttmer and Singhal (2014) trace parallels between tax morale and a concern for the application of the law. The study points to a growing trend in policies that assume that non-pecuniary factors are important to decisions related to compliance with tax legislation. For example, we can cite initiatives in India and various states in the United States which have begun publishing the names of those who have the largest tax debts on public websites, to make these people feel ashamed. In this way, they indicate that the term tax morale can be associated as much with the intrinsic motivation to pay taxes as with the guilt or shame of not paying them. In this sense, it is clear that social recognition or the judgement of one's peers can influence tax compliance.

Pope and Mohdali (2010) reinforce the concept that the way in which other taxpayers deal with tax issues influences an individual's taxpaying decisions. Torgler, Schaffner and Macintyre (2007) argue, in fact, that guilt and remorse can affect citizens in the form of internal sanctions in light of the violation of social norms. The perception that the taxpayer has in terms of how public resources are spent can be correlated with civic duty as well as sociological, cultural and psychological factors, which can positively or negatively affect the level of tax compliance (NICHITA and BATRÂNCEA, 2012; RODRIGUEZ-JUSTICIA and THEILEN, 2018). In the same way, Alm and McClellan (2012) reinforce the thesis that the inclination to pay taxes or not is influenced by various cultural factors which differ among countries.

Torgler (2005) analyzes how the tax burden, when it is correlated with high levels of corruption, can interfere in the perceptions of individuals in terms of tax compliance and contribute to an increase in tax evasion. His study reveals that the discretion of an administrative entity over the allocation of public resources can reinforce the possibility of diverting funds and thus greater corruption. In fact, some taxpayers use evasion as a way of demonstrating their dissatisfaction. Barone and Mocetti (2011) corroborate this thinking when they relate that tax morale increases when the taxpayer perceives that public resources are well managed and are being used in an efficient manner.

On the other hand, Nichita and Batrâncea (2012) discourse about another determinant factor in tax morale: the taxpayer's personal beliefs. This study points out that being religious can be an important determinant in the taxpayer's perception of tax compliance. The idea is to reinforce the concept that the more religious an individual is, the greater this person's inclination towards tax compliance will be, given that ecclesiastic doctrines tend to instruct individuals to reflect morally on what is right 
and what is wrong. In this sense, Pope and Mohdali (2010) also discuss the role that beliefs play in terms of tax obligations, since it is expected that religious people have higher moral values. In fact, it is important to point out that even in the 1960s Hirschi and Stark (1969) indicated that religion can inhibit illegal behavior, since it operates as a system of sanctions that legitimizes and reinforces social values.

Tax evasion reduces the capacity of public entities to provide adequate public services and make the necessary investments to improve management performance (TORGLER, 2005). There is data that demonstrates that an expansion of the parallel economy is another important indicator which helps us understand tax evasion, given that even though informal activities are important to the development of emerging countries, they present difficulties associated in terms of legalizing businesses and dealing with the possibilities of exemptions or reductions in their tax burdens. With this, governments have become more concerned about tax evasion in general, no matter whether it is related to an underestimate of revenues or an overestimate of expenses (POPE and MOHDALI, 2010; BERDIEV and SAUNORIS, 2018).

Within this context, Filippin, Fiorio and Viviano (2013) point out that the greatest legal impositions, through sanctions in terms of fulfilling tax compliance norms, can shape the behavior of taxpayers, given that surveillance can potentially affect tax morale. Thus, it is common to adopt audits and more severe penalties as part of a coercive policy to confront tax evasion, because it is noted that an increase in the inclination to punish violations leads to an increase in taxpayers declaring revenues in a true and faithful manner. However, Nichita and Batrâncea (2012) warn that it is necessary to adopt different strategies of dissuasion to increase tax morale. Economic aspects, such as audits and sanctions, for example, are not the only factors that interfere with tax compliance - as has been stated above.

It must be remembered, however, that morale and tax enforcement interact given that a correlation exists between them. In a rigorously enforced and punitive environment, there is no space for tax morale. On the other hand, if there is no vigilance whatsoever, tax morale will be harmed, because the absence of enforcement efforts will indicate that compliance is not important (LUTTMER and SINGHAL, 2014).

Measuring and evaluating each aspect that makes up tax morale makes it possible to trace strategies and better understand tax compliance. It is true that some individuals value ethics and their moral integrity more, and that this is personal and nontransferrable, no matter whether they consider the tax system to be fair or not. Taxpayers who perceive injustice in terms of the amount of taxes that they pay as compared to how much society receives in return through the services offered by public entities, help answer questions related to decision making and provide evidence for this kind of behavior (POPE and MOHDALI, 2010).

Below we will present our methodological procedures for the data collection and analysis of this study.

\section{METHODOLOGY}

This empirical study relies on the quantitative method in its approach, since it uses statistical instruments to interpret the data. Its objectives are those of an exploratory study.

In terms of scientific procedures, this study uses a survey. This survey was adapted from Torgler, Schaffner and Macintyre (2007), and contained objective multiple-choice questions, which made it possible to collect data from individuals, and it was applied indirectly in an electronic manner. No participant was identified, and this premise made the respondents free to offer their opinions. The survey used the student database of the Fucape Business School (with locations in the states of Espírito Santo, Rio de Janeiro and Maranhão), and it was also applied through a link sent by email to students at Vale do Rio Doce University (Univale), located in Governador Valadares, MG.

In the same manner, the link to access the form was announced on social media websites such as Facebook and WhatsApp, asking participants to pass it on to their contacts in order to attain the maximum number of users during the period established for compiling our data.

This data collection took place between May and August 2017 through the use of a structured form, composed of two segments (see the Appendix). The first - Part A - consisted of objective questions focused on social and demographic characteristics (necessary to compare, for example, whether gender affects tax morale). The same rationale was used in terms of age group, 
income group, state of residence, religious beliefs and marital status. The second segment - Part B - consisted of 10 questions asking for opinions specifically related to tax morale which offered 5 valid alternatives for responses, ranging from strongly agree to strongly disagree ${ }^{1}$.

The proposed survey model was elaborated on the Google Forms electronic platform ${ }^{2}$ and was duly validated by using Cronbach's Alpha coefficient. In accordance with Hair Jr., Anderson, Tatham et al. (2005), the values varied between 0 and 1 - with proximity to 1 indicating greater consistency between the indicators (questions), with values between 0.60 and 0.70 being considered the limit of minimum accepted values. This statistic presented a Cronbach's Alpha value of $0.884-$ a result well above the minimum requirement.

The level of tax morale was measured using a survey consisting of 10 questions, whose responses indicated greater or lesser tax morale. The object of the study was evaluated based on the opinions of those interviewed, which were used to estimate their tax morale and correlate their perceptions with socio-demographic characteristics. The objective phase was accomplished through a quantitative method which sought to trace the behavior of these people in the form of numerical indices based on the collection of fully completed multiple choice surveys.

In this way, through these questions it was possible in this study to associate variables with each of the 5 levels of possible responses, which indicated greater or lesser tax compliance, and as a result, the level of tax morale, namely: 1, when the participant strongly agreed with the statement; 2 , when the participant agreed partially with the statement; 3 , when the participant was neutral, or in other words, neither agreed nor disagreed; 4, when the participant disagreed partially with the statement; and 5, when the participant strongly disagreed with the statement. Therefore, the closer the responses were to 1 , the greater the tendency towards low tax morale; and the closer the responses were to 5 , the greater the tendency toward high tax morale.

To collect more data about tax morale in Brazil, we consulted the website of the Brazilian Digital Library of Theses and Dissertations of the Ministry of Science, Technology, Innovation and Communications; however, the results yielded no publications. Identical results were obtained in the following academic research platforms: EBSCOhost Research Databases, Scientific Periodicals Electronic Library (SPELL) and the Scientific Electronic Library Online (SciELO). This ratifies the information that this is a pioneering study in Brazilian territory.

The statistical analysis of the data was realized using the Stata software package version 13.0, and the multiple linear regression model was represented by the equation below:

$$
\begin{aligned}
\text { TM }_{i}=\beta_{0}+ & \beta_{1} \text { Gender }_{i}+\beta_{2} \text { AgeGroup }_{i}+\beta_{3} \text { MaritalStatus }_{i}+\beta_{4} \text { EducationLevel }_{i} \\
& +\beta_{5} \text { IncomeGroup }_{i}+\beta_{6} \text { Religion }_{i}+\beta_{7} \text { StateofResidence }_{i} \\
& +\beta_{8} \text { ProfSector }_{i}+\varepsilon_{i}
\end{aligned}
$$

$\mathrm{TM}_{\mathrm{i}}$ is the index of tax morale and the betas are coefficients. The random variables evaluated are presented in Box 1.

\section{Box 1}

\section{Independent Variables}

\begin{tabular}{|l|l|}
\hline \multicolumn{2}{|c|}{ Variável } \\
\hline Genderi & Gender: female or male. \\
\hline AgeGroupi & Age group by range. \\
\hline MaritalStatusi & Marital status. \\
\hline EducationLeveli & Level of educationão \\
\hline IncomeGroupi & Income group, evaluated in terms of minimum wage, the national floor. \\
\hline Religioni & Religious or spiritual beliefs. \\
\hline StateofResidencei & State where respondent lives. \\
\hline ProfSectori & Professional sector, the public or private sector. \\
\hline$\varepsilon_{i}$ & Error \\
\hline
\end{tabular}

Source: Elaborated by the authors.

The calculated index which represents the tax morale $\left(\mathrm{TM}_{\mathrm{i}}\right)$ was calculated through a survey adapted from Torgler, Schaffner and Macintyre (2007), composed of 10 indicators on a Likert scale with each statement presenting the following dimensions: 
1 - Strongly agree; 2 - Partially agree; 3 - Neutral (neither agree nor disagree); 4 - Partially disagree; and 5 - Strongly disagree (see Appendix, Part B). The index was constituted by the sum of the responses for each interviewee, with values varying between a minimum of 10 points (strongly agree = low tax morale) and a maximum of 50 points (strongly disagree = high tax morale).

In terms of methodological issues, there are a series of reflections that needed to be addressed from the perspective of this survey's novelty and the choices to be adopted to deal with the challenges that arose. The first great challenge was adapting the survey created by Torgler, Schaffner and Macintyre (2007) to Brazil. It is evident that the local culture and the perception, representation, and symbolic significance processes and the lifestyle and daily contingencies of Brazilians are very particular, and thus creating an intelligible survey that would be appropriate to Brazilian reality would be a challenge. However, we decided that it would be good to maintain the original survey in its entirety as much as possible, and thus we just adjusted the currency to reais and only referred to federal taxes.

In addition, in terms of the methodology there are also a series of limitations that do not invalidate or negate the work done, but looked at from the point of view of self-criticism, assume a relevance that needs to be addressed. Since this is a virtual survey about values and behavior in relation to tax issues that has been spontaneously filled in by the participant, there needs to be a discussion of who the participants who have volunteered to fill out this survey are:

- Would some of them begin to respond and stop in the middle because they would have to express their lack of morality in terms of taxes?

- Would some of them decide not to respond to not run the risk of expressing unacceptable behavior?

These questions point out the limitations of this work in terms of its sample. They should be taken into consideration by future researchers.

Another methodological limitation is related to the way in which the participants were invited to participate in the study and respond to the survey. Given the expressed intent to quantify the tax morale of Brazilian citizens, the sample is limited and does not reflect the diversity of Brazil. However, despite these methodological limitations, this work presents the results of a small sample of volunteer participants, but they have been validated and reflect, even though the sample is partial due to these limitations, the tax morale of a portion of the Brazilian public.

\section{RESULTS AND ANALYSES}

The analyses of the observed results focus on the calibration of possible differences in tax morale related to socio-demographic characteristics, and the evaluation of the regression of the survey responses for ordered probit models (by question), and a linear regression of all of the results.

The subsection below displays the absolute and relative frequencies of the variables, represented by their associated socioeconomic characteristics and the descriptive tax morale statistics associated with them.

\section{Descriptive statistics: The sample profile vs. the tax morale index}

Tables 1 and 2 enable us to distinguish the respondents in terms of their socio-demographic data, in which the following characteristics dominate: male sex (52.9\%); in terms of the age group, $39.6 \%$ of the respondents are between the ages of 25 and 34; and $19.90 \%$ between the ages of 35 and 44; and in terms of marital status, $50.2 \%$ of them are single. In terms of education, $68.0 \%$ have at least a college education; $56.6 \%$ reside in the state of Minas Gerais; $43.7 \%$ are Catholic and $20.6 \%$ are evangelical; $60.5 \%$ earn at most 5 times the minimum wage; and finally, $51.4 \%$ of them work in the private sector.

Through these tables we can conduct an explanatory analysis using descriptive measures - averages, standard deviations, and medians, comparing them in terms of socio-demographic characteristics. In analyzing the statistics for tax morale by gender, we can see that the average and median results were superior among women.

In terms of age groups, the lowest average and median results were observed for those 18 years and younger. The highest tax morale average was observed for those above the age of 64 (12 respondents). Similar results were presented by Torgler, 
Demir, Macintyre et al. (2008) in an empirical study which analyzed the causes and consequences of the public's tax morale; the authors reached the conclusion that in the United States and Turkey women exhibit significantly less tax evasion than men, and in the United States, the elderly display more tax compliance than younger individuals.

Table 1

Descriptive Statistics - Socio-Demographic Variables versus Tax Morale (1)

\begin{tabular}{|c|c|c|c|c|c|c|}
\hline \multirow[b]{2}{*}{ Variable } & \multirow[b]{2}{*}{ Description } & \multirow[b]{2}{*}{$\mathrm{N}$} & \multirow[b]{2}{*}{$\% N$} & \multicolumn{3}{|c|}{ Tax Morale (TM) } \\
\hline & & & & Average & $\begin{array}{l}\text { Standard } \\
\text { Deviation }\end{array}$ & Median \\
\hline \multirow{2}{*}{ Gender } & Female & 320 & $47.1 \%$ & 35.3 & 9.3 & 37.0 \\
\hline & Male & 359 & $52.9 \%$ & 33.7 & 10.6 & 35.0 \\
\hline \multirow{7}{*}{ Age Group } & Up to 18 years old & 14 & $2.1 \%$ & 26.4 & 13.3 & 27.5 \\
\hline & 19 to 24 years old & 130 & $19.1 \%$ & 33.0 & 10.3 & 35.5 \\
\hline & 25 to 34 years old & 269 & $39.6 \%$ & 34.6 & 9.8 & 36.0 \\
\hline & 35 to 44 years old & 135 & $19.9 \%$ & 35.1 & 10.0 & 37.0 \\
\hline & 45 to 54 years old & 75 & $11.0 \%$ & 36.3 & 9.1 & 37.0 \\
\hline & 55 to 64 years old & 44 & $6.5 \%$ & 34.9 & 10.7 & 35.5 \\
\hline & Over 64 years old & 12 & $1.8 \%$ & 36.8 & 9.8 & 37.0 \\
\hline \multirow{5}{*}{ Marital Status } & Single & 341 & $50.2 \%$ & 33.9 & 10.1 & 36.0 \\
\hline & Married & 252 & $37.1 \%$ & 36.0 & 9.2 & 37.0 \\
\hline & Stable Union & 41 & $6.0 \%$ & 29.7 & 11.5 & 32.0 \\
\hline & Divorced & 35 & $5.2 \%$ & 35.3 & 10.9 & 38.0 \\
\hline & Separated/Widow(er) & 10 & $1.5 \%$ & 30.3 & 14.1 & 30.0 \\
\hline \multirow{6}{*}{$\begin{array}{l}\text { Level of } \\
\text { Education }\end{array}$} & Primary Education & 13 & $1.9 \%$ & 20.2 & 9.1 & 20.0 \\
\hline & Secondary Education & 207 & $30.5 \%$ & 32.8 & 9.7 & 34.0 \\
\hline & Higher Education & 145 & $21.4 \%$ & 33.6 & 10.1 & 35.0 \\
\hline & Specialization & 197 & $29.0 \%$ & 36.0 & 10.0 & 38.0 \\
\hline & $\begin{array}{l}\text { Graduate Degree } \\
\text { (Master's or PhD) }\end{array}$ & 117 & $17.2 \%$ & 37.6 & 8.7 & 39.0 \\
\hline & Overall Total & 679 & $100.0 \%$ & 34.5 & 10.1 & 36.0 \\
\hline
\end{tabular}

Source: Elaborated by the authors.

In a study conducted in Germany (FELD, TORGLER and DONG, 2008), age and gender also display a strong influence on tax morale: the older the taxpayer, the higher the tax morale. Women also display significantly greater tax compliance in this country.

In terms of marital status, the highest level of tax morale occurs among those who are married and the lowest among those in stable unions. In terms of education level, those with higher levels of education, display greater tax morale in both the average and median results.

Among the 5 states - Minas Gerais, Espírito Santo, São Paulo, Bahia and Rio de Janeiro - where most of the residents live (almost $90.0 \%$ of the sample), the highest average index was observed in Rio de Janeiro (35.9) and the lowest was observed in São Paulo (30.1).

In terms of religion versus tax morale, the highest average was verified among spiritists and the lowest among those who believe in God and don't have a religion. In this sense, religion also had a significant positive impact on citizens in Germany (FELD, TORGLER and DONG, 2008), reinforcing the idea that being religious exerts a systematic influence on tax morale, making it therefore a restriction in terms of citizens engaging in tax evasion (TORGLER, 2007).

Analyzing the results by income groups, we can perceive a similar logic to that of education level. In other words, the higher an individual's income group, the greater the average (and median) level of tax morale. Finally, when evaluating the average 
tax morale by professional sector, we see lower results for those in the private sector and those who responded "N/A", and higher results for workers in the public sector.

Table 2

Descriptive Statistics - Socio-Demographic Variables versus Tax Morale (2)

\begin{tabular}{|c|c|c|c|c|c|c|}
\hline \multirow[b]{2}{*}{ Variable } & \multirow[b]{2}{*}{ Description } & \multirow[b]{2}{*}{$\mathrm{N}$} & \multirow[b]{2}{*}{$\% \mathrm{~N}$} & \multicolumn{3}{|c|}{ Tax Morale (TM) } \\
\hline & & & & Average & $\begin{array}{l}\text { Standard } \\
\text { Deviation }\end{array}$ & Median \\
\hline \multirow{6}{*}{$\begin{array}{l}\text { State of } \\
\text { Residence }\end{array}$} & Minas Gerais & 384 & $56.6 \%$ & 35.2 & 9.9 & 37.0 \\
\hline & Espírito Santo & 112 & $16.5 \%$ & 35.4 & 9.8 & 37.0 \\
\hline & São Paulo & 53 & $7.8 \%$ & 30.1 & 11.6 & 29.0 \\
\hline & Bahia & 31 & $4.6 \%$ & 31.3 & 7.6 & 30.0 \\
\hline & Rio de Janeiro & 30 & $4.4 \%$ & 35.9 & 9.6 & 39.5 \\
\hline & Other States & 69 & $10.2 \%$ & 33.4 & 10.7 & 32.0 \\
\hline \multirow{6}{*}{ Religion } & Catholic & 297 & $43.7 \%$ & 34.1 & 9.9 & 35.0 \\
\hline & Evangelical & 140 & $20.6 \%$ & 34.1 & 9.7 & 36.0 \\
\hline & $\begin{array}{l}\text { Believes in God, but has } \\
\text { no religion }\end{array}$ & 121 & $17.8 \%$ & 33.8 & 10.4 & 35.0 \\
\hline & Spiritist & 52 & $7.7 \%$ & 38.2 & 8.7 & 38.5 \\
\hline & Atheist & 43 & $6.3 \%$ & 34.9 & 13.1 & 39.0 \\
\hline & Others & 26 & $3.8 \%$ & 35.5 & 8.1 & 37.5 \\
\hline \multirow{5}{*}{ Income Group } & Up to $2 \times M W$ & 210 & $30.9 \%$ & 33.1 & 9.9 & 36.0 \\
\hline & From 2.1 to $5 \times \mathrm{MW}$ & 201 & $29.6 \%$ & 33.7 & 9.7 & 33.0 \\
\hline & From 5.1 to $10 \times \mathrm{MW}$ & 131 & $19.3 \%$ & 35.3 & 10.3 & 38.0 \\
\hline & From 10.1 to $20 \times \mathrm{MW}$ & 72 & $10.6 \%$ & 36.6 & 10.7 & 39.0 \\
\hline & More than $20 \times \mathrm{MW}$ & 65 & $9.6 \%$ & 37.2 & 9.7 & 39.0 \\
\hline \multirow{5}{*}{$\begin{array}{l}\text { Professional } \\
\text { Sector }\end{array}$} & Private Sector & 349 & $51.4 \%$ & 33.6 & 10.1 & 35.0 \\
\hline & Public Sector & 181 & $26.7 \%$ & 36.5 & 9.6 & 38.0 \\
\hline & Both & 56 & $8.2 \%$ & 35.3 & 9.9 & 34.5 \\
\hline & N/A & 93 & $13.7 \%$ & 33.2 & 10.5 & 34.0 \\
\hline & Overall Total & 679 & $100,0 \%$ & 34.5 & 10.1 & 36.0 \\
\hline
\end{tabular}

Source: Elaborated by the authors.

In Tables 1 and 2 we have seen that a number of characteristics in this exploratory analysis present differences in relation to the level of tax morale. And the objective of this study is to evaluate exactly whether these presented differences are significant or not.

In evaluating the statistics associated with the tax morale index, represented by a sum of indicators, we found an average of 34.5 , a result that could be interpreted as somewhere between a neutral response and partially disagree, making an analogy with the Likert scale used in this study. It should be noted that the 75 percentile value was 43 , which can be interpreted as $25 \%$ of the respondents disagree partially or totally in terms of the tax morale index. It's important to emphasize that the closer the result is to 50 , the higher the individual's tax morale index is.

\section{The regression model statistics}

In this study, we have applied a multiple regression model when the dependent variable was the tax morale (TM) index. When the dependent variable was one of the indicators, we opted to use the probit regression model. In both we have sought to demonstrate statistically possible differences between the socio-demographic variables and the TM index, as well as the differences between each of the indicators which represents the index. Table 3 presents the regression estimates. 
Analyzing the statistics for the dependent TM variable, we have found that the tax morale of women is significantly superior to that of men to a significance level of $10 \%$. In terms of the age group, we found no significant difference in terms of tax morale. For marital status, there was a significant difference (1\%) with a negative coefficient for respondents in a stable union, or in other words, on average the tax morale of these respondents was lower when compared to single, married, divorced and separated/widow(er) respondents.

In evaluating the difference in tax morale by education level, we found to a significance level of $1 \%$ that those with more education had higher levels of tax morale. In terms of the states of residence of this sample, we found that residents of São Paulo had lower values for tax morale than the other respondents; the same was true for Bahia, but with a smaller coefficient than the coefficient observed for São Paulo.

In terms of religion, those who were spiritists had greater levels of tax morale at a $5 \%$ level of significance; the other religious beliefs, on the other hand, did not present significant differences. The various income groups also did not present significant differences in terms of tax morale. Considering professional sectors, higher values were found for public servants as compared to the other respondents. 


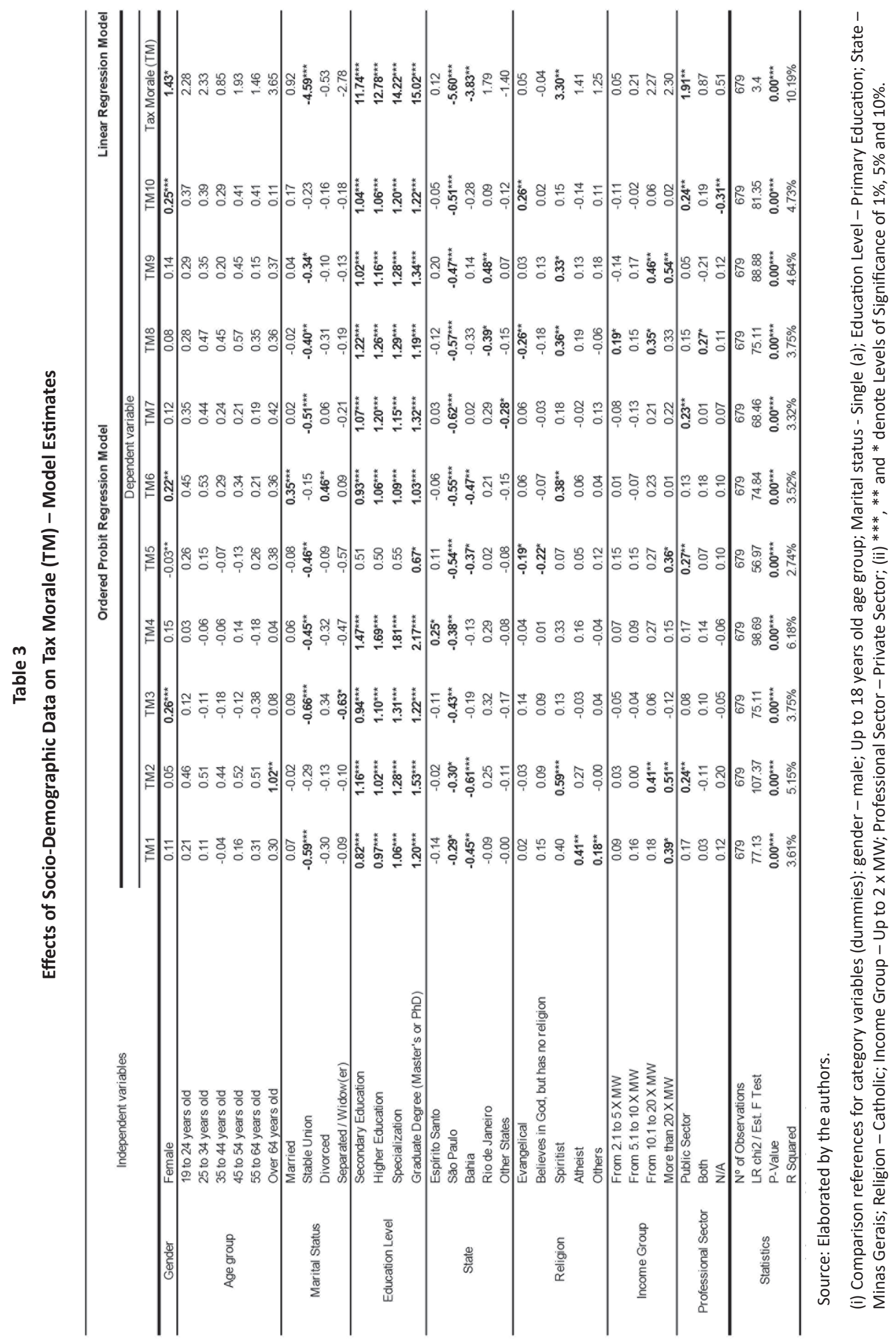




\section{CONCLUSIONS}

This study has sought, in a pioneering manner in this country, to quantify the tax morale of Brazilians. To accomplish this, we began with concepts of tax morale defined in previous studies by a series of researchers as explained in the theoretical reference section.

In analyzing the entire research process beginning with the theoretical references and the methodological choices presented here, a series of reflections and possibilities have emerged in terms of the order of three distinct spheres, these being theory, methodology and social relevance, which have been addressed here in this order.

From a theoretical point of view, our objective of identifying and quantifying the tax morale of Brazilians is a vanguard initiative, because it applies to Brazil advances in scientific research and theory in terms of tax morale and tax enforcement issues that have been obtained by renowned scientists from all over the world. From this perspective, it also opens up avenues of research into the scientific concepts and perspectives related to tax morale and tax enforcement issues that should be adopted in Brazil.

The fact that this is a pioneering study in this country brings with it a series of challenges, including having to proceed along new paths involving unexpected concerns. Various issues ended up requiring a series of choices and decisions along the way, as well as the uncertainty of whether we were proceeding on the right path or not. In addition to all this, this study seeks to quantify in an objective manner perceptions and behavior of a moral nature which adds a unique form of complexity to this undertaking. Revealing this path and introducing these concepts and perspectives to Brazil is extremely relevant from a theoretical point of view, because it broadens the field of tax morale and tax enforcement. Without a doubt, future studies in this area will be treading on firmer ground based on the path this study has blazed.

What is certain is that despite some methodological limitations, this study presents a series of valid results which have been analyzed in detail through the use of statistical models which have demonstrated their relevance. The most important issue from a methodological point of view is that the limitations presented can be taken into account in future studies of this subject to advance our understanding of this area. The results and analyses performed demonstrate relevant data, which even though it is still partial and limited, should be considered from a scientific and methodological point of view and in terms of its social relevance.

In terms of this social relevance, historically in Brazil there has been a complicated relationship between the country's citizens and the state, but even in light of these tensions and conflicts, tax obligations have remained a constant which permeates the lives of citizens and the implementation of these obligations will remain a part of the daily lives of Brazilians whether they like it or not. Trying to quantify the tax morale of Brazilian citizens consists of opening paths to the establishment of specific, efficient public policies related to tax education, awareness, and a new approach to the significance attached to social processes in the relationships between citizens, the state and taxation.

Finally, after all this analysis and reflection, recognizing its methodological limits, but also bearing in mind the difficulties and challenges that result from conducting pioneering studies, and considering the theoretical and social relevance and the veracity and reliability of the data obtained using the applied statistical methods, we hope that new studies will be developed in Brazil and that science will continue to advance in this area to improve its concepts, methods and models, and above all, transform our social reality. This is the first step on a long journey. 


\section{REFERENCES}

ALLINGHAM, M. G.; SANDMO, A. Income tax evasion: a theoretical analysis. Journal of Public Economics, v. 1, n. 3-4, p. 323-338, 1972.

ALM, J.; MCCLELLAN, C. Tax morale and tax compliance from the firm's perspective. Kyklos, v. 65, n. 1, p. 1-17, 2012.

BARONE, G.; MOCETTI, S. Tax morale and public spending inefficiency. International Tax Public Finance, v. 18, n. 732, p. 1-29, 2011.

BECKER, G. S. Crime and punishment: an econometric approach. Journal of Political Economy, v. 76, p. 169-217, 1968.

BERDIEV, A. N.; SAUNORIS, J. W. What drives entrepreneurs underground? The role of tax morale. Applied Economics Letters, p. 1-5, 2018.

BRAITHWAITE, V.; AHMED, E. A threat to tax morale: the case of Australian Higher Education policy. Journal of Economic Psychology, v. 26, n. 4, p. 523-540, 2005.

DOERRENBERG, P.; PEICHL, A. Progressive taxation and tax morale. Public Choice, v. 155, n. 3-4, p. 293-316, 2013.

FELD, L. P.; TORGLER, B.; DONG, B. Coming closer? Tax morale, deterrence and social learning after German unification. Basel: Center for Research in Economics, Management and the Arts, 2008. (CREMA Working Paper Series, 2008-09).

FILIPPIN, A.; FIORIO, C. V.; VIVIANO, E. The effect of tax enforcement on tax morale. European Journal of Political Economy, v. 32, p. $320-$ 331, 2013.

GERSTENBLÜTH, M. et al. How do inequality affect tax morale in Latin America and Caribbean? Revista de Economía del Rosario, v. 15, n. 2, p. 123-135, 2012.

HAIR JUNIOR, J. F. et al. Análise multivariada de dados. 5. ed. Porto Alegre: Bookman, 2005.

HIRSCHI, T.; STARK, R. Hellfire and delinquency. Social Problems, v. 17, n. 2, p. 202-313, 1969.

HORODNIC, I. A. Tax morale and institutional theory: a systematic review. International Journal of Sociology and Social Policy, v. 38, n. 9-10, 2018.

LUTTMER, E. F. P.; SINGHAL, M. Tax morale. Journal of Economic Perspectives, v. 28, n. 4, p. 149-168, 2014.
MOLERO, J.; PUJOL, F. Walking inside the potential tax evader's mind: tax morale does matter. Journal of Business Ethics, v. 105, n. 2, p. 151-162, 2012.

NICHITA, R.-A.; BATRÂNCEA, L.-M. The implications of tax morale on tax compliance behavior. Annals of the University of Oradea: Economic Science Series, v. 21, n. 1, p. 739-744, 2012.

ORVISKA, M.; HUDSON, J. Tax evasion, civic duty and the law abiding citizen. European Journal of Political Economy, v. 19, n. 1, p. 83-102, 2003.

POPE, J.; MOHDALI, R. The role of religiosity in tax morale and tax compliance. Australian Tax Forum, v. 25, n. 4, p. 565-596, 2010.

PRIBERAM. Dicionário Priberam da Língua Portuguesa. [2017]. Available at: <https://www.priberam.pt/dlpo/moral>. Accessed on: June 12, 2017.

RODRIGUEZ-JUSTICIA, D.; THEILEN, B. Education and tax morale. Journal of Economic Psychology, n. 64, p. 18-48, 2018.

SANTIAGO, J. C. Moralidade tributária: um projeto de estudos para a fundamentação da tributação no Brasil. Revista de Finanças Públicas, Tributação e Desenvolvimento, v. 3, n. 3, p. 1-45, 2015.

TORGLER, B. Speaking to theorists and searching for facts: tax morale and tax compliance in experiments. Journal of Economic Surveys, v. 16, n. 5, p. 657-683, 2002.

TORGLER, B. Tax morale in Latin America. Public Choice, v. 122, n. 1-2, p. 133-157, 2005.

TORGLER, B. Tax compliance and tax morale: a theoretical and empirical analysis. Cheltenham: Edward Elgar, 2007.

TORGLER, B.; SCHAFFNER, M.; MACINTYRE, A. Tax compliance, tax morale and governance quality. St. Louis: Center for Research in Economics, Management and the Arts, 2007. (Working Paper Series, 2007-17).

TORGLER, B. et al. Causes and consequences of tax morale: an empirical investigation. Economic Analysis \& Policy, v. 38, n. 2, p. 313-339, 2008.

WILLIAMS, C. C.; KRASNIQI, B, Evaluating the individual- and countrylevel variations in tax morale: evidence from 35 Eurasian countries. Journal of Economic Studies, v. 44, n. 5, 2017.

Antonio Lopo Martinez

ORCID: https://orcid.org/0000-0001-9624-7646

PhD Student in Law (University of Coimbra/University of Salamanca); PhD in Accounting from FEA-USP; Master's in Administration from the University of California at Berkeley; Visiting Researcher at Georgetown University Law Center, Washington. D.C., U.S. E-mail: antoniolopo@terra.com.br

Marcelo Lopes Bello Coelho

ORCID: https://orcid.org/0000-0001-8575-9275

PhD Student and Master's in Accounting from Fucape Business School; Professor at Vale do Rio Doce University (UNIVALE), Governador Valadares MG, Brazil. E-mail: marcelolopesbello@hotmail.com 


\section{APPENDIX}

\section{SURVEYS}

PART A: Questions regarding socio-demographic data

GENDER:

$\square$ Female

$\square$ Male

STATE:

\begin{tabular}{|c|c|c|c|c|c|c|}
\hline$\square \mathrm{AC}$ & $\square \mathrm{AL}$ & $\square \mathrm{AP}$ & $\square \mathrm{AM}$ & $\square \mathrm{BA}$ & $\square \mathrm{CE}$ & \\
\hline$\square \mathrm{DF}$ & $\square$ ES & $\square \mathrm{GO}$ & $\square \mathrm{MA}$ & $\square \mathrm{MT}$ & $\square \mathrm{MS}$ & $\square \mathrm{MG}$ \\
\hline $\mathrm{PA}$ & $\square \mathrm{PB}$ & $\square \mathrm{PR}$ & $\square \mathrm{PE}$ & $\square \mathrm{PI}$ & $\square \mathrm{RJ}$ & $\square \mathrm{RN}$ \\
\hline RS & $\square \mathrm{RO}$ & $\square \mathrm{RR}$ & $\square \mathrm{SC}$ & $\square \mathrm{SP}$ & $\square \mathrm{SE}$ & $\square$ TO \\
\hline
\end{tabular}

MARITAL STATUS:
$\square$ Married
$\square$ Divorced
$\square$ Separated
$\square$ Single
$\square$ Stable Union
$\square$ Widow(er)

AGE GROUP:
$\square$ Up to 18 years old
$\square 19$ to 24 years old
$\square 25$ to 34 years old
$\square 35$ to 44 years old
$\square 45$ to 54 years old
$\square 55$ to 64 years old
$\square$ Over 64 years old

EDUCATION LEVEL:

$\square$ Incomplete Primary Education
$\square$ Completed Primary Education
$\square$ Incomplete Secondary Education
$\square$ Completed Secondary Education
$\square$ Incomplete Higher Education
$\square$ Completed Higher Education
$\square$ Incomplete Specialization (Graduate School)
$\square$ Completed Specialization (Graduate School) 


\author{
$\square$ Incomplete Master's Degree \\ $\square$ Completed Master's Degree \\ $\square$ Incomplete PhD \\ Completed PhD
}

INCOME GROUPS:
$\checkmark$ Up to 2 times minimum wage
From 2.1 to 5 times minimum wage
From 5.1 to 10 times minimum wage
From 10.1 to 20 times minimum wage
More than 20 times minimum wage

BELIEFS/RELIGION:

$\square$ Atheist

$\square$ Believes in God, but does not have a religion.

$\square$ Catholic

$\square$ Evangelical

$\square$ Spiritist

$\square$ Buddhist

$\square$ Others:

PROFESSION:

$\square$ Business Administrator
$\square$ Lawyer
$\square$ Systems Analyst
$\square$ Accountant
$\square$ Economist
$\square$ Business Owner
$\square$ Student
$\square$ Doctor
$\square$ Professor
$\square$ Secretary
$\square$ Others:

PROFSSIONAL SECTOR:

$\square$ Public Sector

$\square$ Private Sector

$\square$ Both

$\square \mathrm{N} / \mathrm{A}$ 


\title{
CADERNOS EBAPE.BR
}

\section{PART B: Opinion questions}

1. Given the current tax burden, it is difficult to criticize those who do not pay taxes.

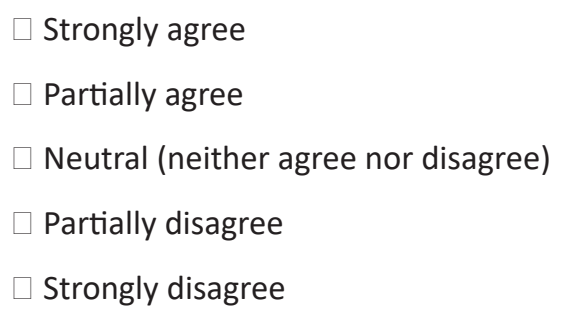

2. Given how easy it is and the opportunities that there are for tax evasion, it is difficult to criticize those who do this.

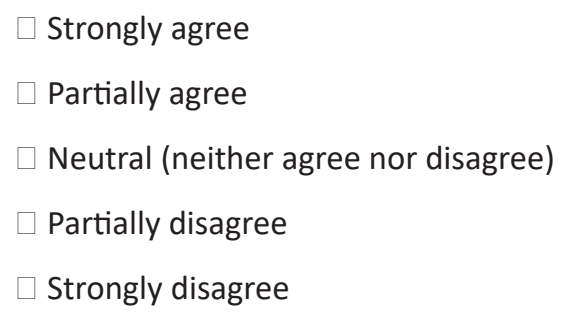

3. If I'm in doubt about whether to declare or not declare a certain amount of income, I choose not to declare.

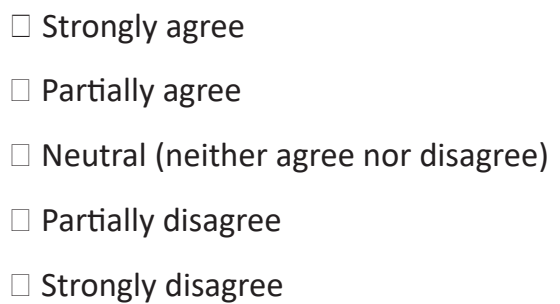

4. Given that the government receives enough money through taxation, it doesn't make a difference if some people don't pay taxes.

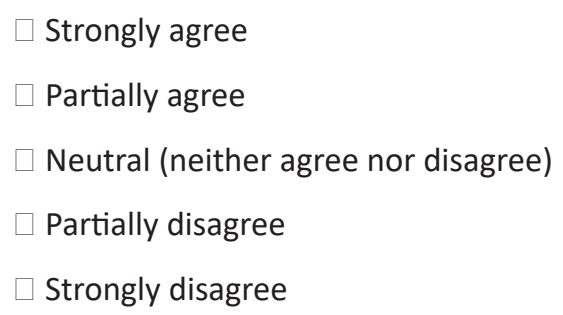

5. The tax burden is so heavy that not paying taxes is an economic necessity for the survival of many people and companies.

\author{
$\square$ Strongly agree \\ Partially agree \\ $\checkmark$ Neutral (neither agree nor disagree) \\ Partially disagree \\ $\checkmark$ Strongly disagree
}


6. If I receive $R \$ 200.00$ in cash for providing services, I don't declare it.

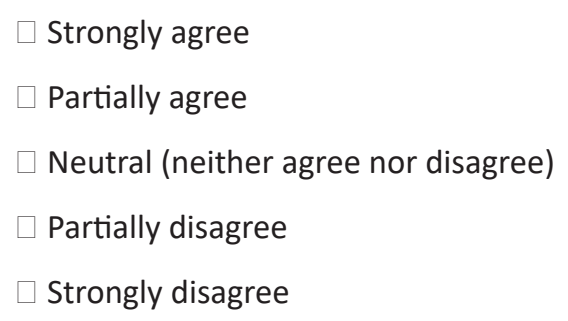

7. Omitting (not informing) taxable income is justifiable in light of the unfairness of the tax system.

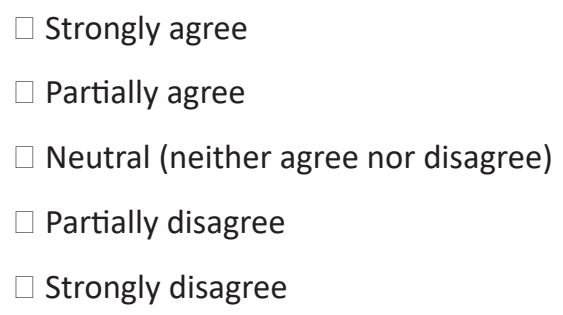

8. Taxes are something that takes my money away from me.

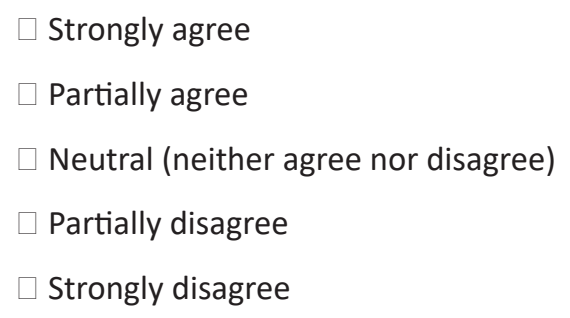

9. Given that everyone cheats on their taxes, it's difficult to criticize those who do.

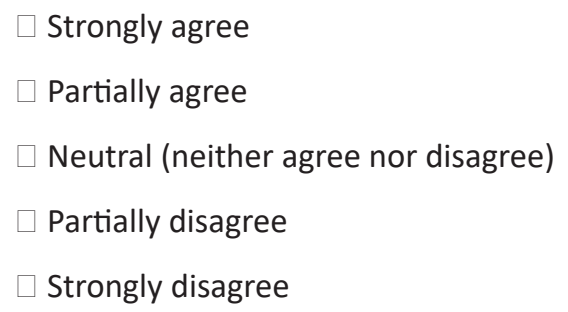

10. There's nothing wrong with omitting income in my income tax declaration.

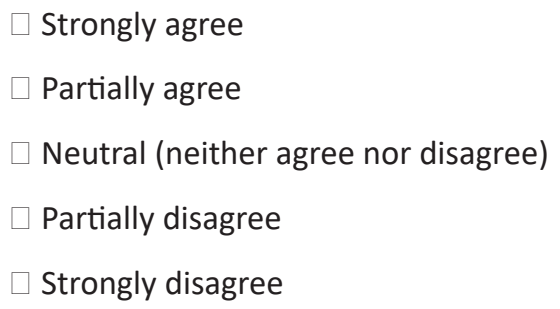

NOTES:

'This measurement was possible through the use of a 5-point Likert scale.

ii Available at: <https://goo.gl/forms/Q3Tp7DZBeBCYazkd2>. Accessed on: Sept. 01, 2017. 